\title{
Non adherence to Antihypertensive medications among hypertensive elderly patients in outpatient geriatric clinic
}

\author{
Sarah A. Hamza , Rania M. El Akkad , Ekramy E. Abdelrahman ,Sherief A. Abd elghany a \\ Department of Geriatrics and Gerontology, Faculty of Medicine, Ain Shams University
}

\begin{abstract}
Background: Hypertension is an important public health challenge worldwide. Non-adherence to antihypertensive treatment is a big obstacle in blood pressure control and predispose to disease progression to complications.
\end{abstract}

Aim: to determine adherence to antihypertensive medications among elderly patients, and to elicit factors associated with poor adherence among elderly hypertensive.

Methods: A cross sectional study was done on 160 elderly hypertensive patients gathered from el Demerdash outpatient clinic, Ain Shams university hospital, Cairo, Egypt. The Hill bone scale was used to assess adherence to antihypertensive drugs.

Results: According to Hill Bone Scale for assessment of adherence to anti-hypertensive medications the prevalence was $62.7 \%$ of the studied cases were non adherent to medications, while $37.3 \%$ were adherent to their antihypertensive medications. The findings of this study show that the significant factors that influence antihypertensive treatment adherence are sociodemographic factors such as Age marital status, education, income, occupation, health-related factors, patients' knowledge about hypertension and antihypertensive medication adherence.

Conclusions: Advocacy of adherence to antihypertensive drugs should be inculcated in each and every hypertensive patient along with regular and uninterrupted drug supply and high quality health care service in all health care organizations where health education and counseling gets the highest priority

Keywords: adherence, compliance, Egyptian elderly, elderly

\section{Background}

Hypertension prevalence increases with age, and is a readily treatable risk factor for the most common causes of morbidity and mortality in older age: stroke, ischaemic heart disease, renal insufficiency and dementia

(Ferri et al .,2011)(1).Hypertension is the leading risk factor for mortality and the third cause of disability world wide .by the year 2025, it is estimated that there will be 1.65 billion patient with hypertension (Ezzati et al.,2002)(2). Medication adherence is defined as the extent to which a person's behavior agrees with the agreed medication regimen from a health care provider. (leporini et al.,2014)(3). Addressing the issue of adherence in hypertensive patients focuses on three major issues: effective measurements of adherence, prevalence and predictors of adherence, and effective strategies for improving adherence.( Hovstadius ,2011)(4). Reasons for nonadherence can be broadly classified into patient factors, medication factors, health care provider factors, health care system factors, and socioeconomic factors( sabate ,2003)(5). Potential causes for Non-Adherence include Complex medication regimens ,Convenience factors (eg, dosing frequency),Behavioral factors, Treatment of asymptomatic conditions, affordability, Side effect profiles of medications, Severity of the problem, Patient disagreeing with therapeutic plan .( Munger et al.,2007)(6). Poor adherence may have a major effect on clinical outcome, lead to notable worsening of disease, increased health care costs and even death ( Pasina et al., 2014)(7)

Several studies done on the prevelance of non- 
adherence to anti-hypertensive medications showed a wide range of results. The non-adherence rate in a global study conducted was $45 \%$ and a significant number of the hypertensive patients with co-morbidities were non-adherent to treatment14 [8] . The nonadherence rate from community-based studies in Bangladesh and Vietnam were as high as 85 and $49.8 \%$ respectively .Several factors have been associated with non-adherence as forgetfulness, lack of motivation due to the incurable nature of the disease, absence of symptoms, use of herbal preparation, physical disability, presence of complications, low level of education, poor knowledge of the disease and ignorance on the need for long-term treatment

In the elderly, failure to adhere to medical recommendations and treatment has found to increase the likelihood of therapeutic failure and to be responsible for unnecessary complications, leading to increased spending on health care, as well as to disability and early death. So, we decided to conduct this study to assess adherence to antihypertensive medications among elderly patients, and to elicit factors associated with poor adherence among elderly hypertensives.

\section{Methods}

The study was a cross sectional study on 150 elderly patients gathered from outpatient geriatric clinic, el Demerdash outpatient clinic, Ain Shams university hospital, Cairo, Egypt, more than or equal 60 years old hypertensive patients, male or female, who were on anti-hypertensive medications for at least last 6 months and attended the clinic during the study period. Accepting to participate in the study and gave oral informed consent

-Delirious patients and patients with communication difficulties that hinder completing the tests were excluded from the study.All participants were subjected to the following:

Comprehensive geriatric assessment, including: History taking: Demographic and socio-economic profile, co-morbidities, Detailed Drug history including drugs used for hypertension, such as names of medications used, dosage, and reasons for using antihypertensive medications, as well as any side effects experienced. Complete physical examination with special consideration of measurement of blood pressure. Cognitive function assessment by using the Arabic version (9) (El-Okl et al., 2002) of mini-mental status examination (10) (MMSE) (Folstein et al., 1975).

2. Mood assessment: using Geriatric Depression scale (GDS15)(11)(Yesavage et al., 1983) Using the Arabic version(12) (Shehata et al.,1998) 3. Functional assessment using activities of daily living (ADL)(13)

(Katz et al., 1963 )and Instrumental activities of daily living (IADL) (Lawton and Brody., 1969).(14) Adherence to anti-hypertensive medications assessment:

1. First by direct questioning to all patients and know if they adherent or not 2.Second by using Hill bone scale (HBS) (15): The use of the Hill-Bone scale (Kim, Hill, Bone, \& Levine, 2000) was based on the reported high validity and reliability of this scale when used in a variety of research contexts (16).

\section{Arabic hill bone}

We used the modified Arabic version of the Hill-Bone scale, using nine items which measure adherence, demonstrated an acceptable level of reliability and validity, which consist of 9 questions added to each other Each item is assessed using a four-point Likert scale $(1=$ none of the time, $2=$ some of the time, $3=$ most of the time, and $4=$ all of the time) (17). (Kim et al., 2000)

For the purpose of comparison, participants with none of the time and some of the time were considered to have a good adherence and those with most of the time and all of the time were considered to be having poor adherence to medication.

Statistical analysis: The statistical analysis of the research was performed with the SPSS 22.0 package program. Descriptive statistics were carried out for all variables and expressed as mean and \pm SD for quantitative data, whereas qualitative data were expressed as numbers and percentages. For quantitative data: comparison between groups' mean age was done by using independent $t$ test while for qualitative data: comparison between groups' categories levels was done using chi-square test. A $\mathrm{P}$ value of $\leq 0.05$ was chosen as a level of significance and $\leq 0.01$ as a level of high significance.

\section{Results}

Out of total 150 study participants; $41.3 \%$ belonged to 60-69 years age group, followed by

$32.7 \%$ in $70-79$ years age group, while $26 \%$ were 80 years or older and Most of the study subjects $52.7 \%$ were females and $47.3 \%$ were males. most of the participants were widow $53.3 \%$.

$43.3 \%$ of the study population was illiterate, $72 \%$ had insufficient income, $80 \%$ were living with their families, $69.3 \%$ were nonsmokers and $74 \%$ were not working.

Assessment of cognitive function by MMSE about $60.7 \%$ had no cognitive impairment and $22 \%$ had mild cognitive impairment, according to GDS $63.3 \%$ were not depressed. Functional assessment by ADL and IADL found that $47.3 \%$ were independent.

$51.3 \%$ of cases were found to have HTN only with no co morbid diseases, the most prevalent co morbid disease with HTN was DM $24.7 \%$, then HF $20.7 \%$, then renal impairment $13.3 \%$.

Most of the hypertensive patients $38.7 \%$ had HTN from 1 to 10 years, $32.7 \%$ had their HTN from 6 months to 1 year and $28.7 \%$ had HTN from more than 10years.

The most prevalent type of antihypertensive taken by the cases was beta blockers $29 . \%$, ACEI $28.7 \%$ and 
CCBs $18.7 \%$. $65.3 \%$ of the participants take their antihypertensive medications once per day, $19.3 \%$ take their medications 3 times a day and $15.3 \%$ take it twice a day $72 \%$ take up to 5 medications while $28 \%$ take more than 5 medications (polypharmacy)

On measuring blood pressure $74.7 \%$ of the participants had uncontrolled blood pressure, while $25.3 \%$ had controlled blood pressure.

Most of the participants did not perceive any side effects from their antihypertensive medications $51.3 \%$, about $15.3 \%$ had dry cough or metallic taste with ACEI and $14.7 \%$ perceived lower limb edema with CCBs.

According to Hill Bone Scale for assessment of adherence to anti-hypertensive medications the prevalence was $62.7 \%$ of the studied cases were non adherent to medications, while $37.3 \%$ were adherent to their antihypertensive medications.

The presence of comorbidities was a highly significant predictor of antihypertensive medications adherence in the current study, as patients with hypertension only are more adherent to antihypertensive Medications more than hypertension with other comorbidities

In this study, we found that GDS is a highly significant predictor for adherence, also non demented patient are the commonest group adherent to anti-hypertensive medications, and severe dementia are least group adhere to medications. ADL and IADL are highly significant predictor for adherence.

Table (2): Direct questioning about adherence to medication, IADL

\begin{tabular}{|c|c|c|c|}
\hline \multirow{3}{*}{$\begin{array}{l}\text { Direct } \\
\text { questioning }\end{array}$} & & No. & $\%$ \\
\hline & Adherent & 56 & $37.3 \%$ \\
\hline & $\begin{array}{l}\text { Non } \\
\text { adherent }\end{array}$ & 94 & $62.7 \%$ \\
\hline \multirow[t]{9}{*}{ IADL } & Score 0 & 17 & $11.3 \%$ \\
\hline & Score 1 & 14 & $9.3 \%$ \\
\hline & Score 2 & 29 & $19.3 \%$ \\
\hline & Score 3 & 20 & $13.3 \%$ \\
\hline & Score 4 & 24 & $16.0 \%$ \\
\hline & Score 5 & 16 & $10.7 \%$ \\
\hline & Score 6 & 24 & $16.0 \%$ \\
\hline & Score 7 & 6 & $4.0 \%$ \\
\hline & Score 8 & 0 & $0.0 \%$ \\
\hline
\end{tabular}

Table 1: Descriptive data of the studied parameters

\begin{tabular}{|c|c|c|c|}
\hline & & No. & $\%$ \\
\hline \multirow[t]{3}{*}{ Age } & $60-69$ yrs & 62 & $41.3 \%$ \\
\hline & $70-79$ yrs & 49 & $32.7 \%$ \\
\hline & $\begin{array}{l}80 \text { yrs or } \\
\text { more }\end{array}$ & 39 & $26.0 \%$ \\
\hline \multirow[t]{2}{*}{ Sex } & Male & 71 & $47.3 \%$ \\
\hline & Female & 79 & $52.7 \%$ \\
\hline \multirow[t]{4}{*}{ Marital status } & Married & 53 & $35.3 \%$ \\
\hline & Widow & 80 & $53.3 \%$ \\
\hline & Divorced & 8 & $5.3 \%$ \\
\hline & Not married & 9 & $6.0 \%$ \\
\hline \multirow[t]{5}{*}{ Education } & Illeterate & 65 & $43.3 \%$ \\
\hline & $\begin{array}{l}\text { Can read and } \\
\text { write }\end{array}$ & 31 & $20.7 \%$ \\
\hline & Primary & 22 & $14.7 \%$ \\
\hline & Secondary & 13 & $8.7 \%$ \\
\hline & High level & 19 & $12.7 \%$ \\
\hline \multirow[t]{9}{*}{ Comorbidities } & HTN only & 77 & $51.3 \%$ \\
\hline & $\begin{array}{l}\text { Other co } \\
\text { morbidities } \\
\text { with HTN }\end{array}$ & 73 & $48.7 \%$ \\
\hline & DM & 37 & $24.7 \%$ \\
\hline & $\mathrm{HF}$ & 31 & $20.7 \%$ \\
\hline & Stroke & 13 & $8.7 \%$ \\
\hline & $\begin{array}{l}\text { Ischemic } \\
\text { HD }\end{array}$ & 16 & $10.7 \%$ \\
\hline & malignancy & 14 & $9.3 \%$ \\
\hline & $\begin{array}{l}\text { Renal } \\
\text { failure } \\
\text { (impairment } \\
\text { ) }\end{array}$ & 20 & $13.3 \%$ \\
\hline & $\begin{array}{l}\text { Liver cell } \\
\text { failure }\end{array}$ & 18 & $12.0 \%$ \\
\hline \multirow{4}{*}{$\begin{array}{l}\text { Minimental } \\
\text { status } \\
\text { examination }\end{array}$} & MCI & 33 & $22.0 \%$ \\
\hline & $\begin{array}{l}\text { Moderate } \\
\text { dementia }\end{array}$ & 17 & $11.3 \%$ \\
\hline & $\begin{array}{l}\text { Severe } \\
\text { dementia }\end{array}$ & 9 & $6.0 \%$ \\
\hline & Not deminted & 91 & $60.7 \%$ \\
\hline \multirow[t]{2}{*}{ GDS } & Depressed & 55 & $36.7 \%$ \\
\hline & $\begin{array}{l}\text { Not } \\
\text { depressed }\end{array}$ & 95 & $63.3 \%$ \\
\hline \multirow{3}{*}{$\begin{array}{l}\text { ADL and } \\
\text { IADL }\end{array}$} & Independent & 71 & $47.3 \%$ \\
\hline & Assisted & 63 & $42.0 \%$ \\
\hline & Dependent & 16 & $10.7 \%$ \\
\hline \multirow[t]{4}{*}{$\begin{array}{l}\text { Hill bone } \\
\text { scale }\end{array}$} & $\begin{array}{l}\text { Non of the } \\
\text { time }\end{array}$ & 21 & $14.0 \%$ \\
\hline & $\begin{array}{l}\text { Some of the } \\
\text { time }\end{array}$ & 32 & $21.3 \%$ \\
\hline & $\begin{array}{l}\text { Most of the } \\
\text { time }\end{array}$ & 52 & $34.7 \%$ \\
\hline & $\begin{array}{l}\text { All of the } \\
\text { time }\end{array}$ & 45 & $30.0 \%$ \\
\hline
\end{tabular}


Hamza SA. EJGG.2019; 6(1):10-16

Table (3): Comparison between adherent and non-adherent cases regarding demographic data, Health related factors, Geriatric domains

\begin{tabular}{|c|c|c|c|c|c|c|}
\hline & & \multicolumn{2}{|c|}{ Adherent } & \multicolumn{2}{|c|}{ Non adherent } & \multirow[t]{2}{*}{ P-value } \\
\hline & & No. & $\%$ & No & $\%$ & \\
\hline \multirow[t]{3}{*}{ Age } & $60-69$ yrs & 35 & $62.5 \%$ & 27 & $28.7 \%$ & \multirow[t]{3}{*}{0.000} \\
\hline & $70-79$ yrs & 17 & $30.4 \%$ & 32 & $34.0 \%$ & \\
\hline & 80 yrs or more & 4 & $7.1 \%$ & 35 & $37.2 \%$ & \\
\hline \multirow[t]{2}{*}{ Sex } & Male & 28 & $50.0 \%$ & 43 & $45.7 \%$ & \multirow[t]{2}{*}{0.614} \\
\hline & Female & 28 & $50.0 \%$ & 51 & $54.3 \%$ & \\
\hline \multirow[t]{4}{*}{ Marital status } & Married & 27 & $48.2 \%$ & 26 & $27.7 \%$ & \multirow[t]{4}{*}{0.011} \\
\hline & Widow & 20 & $35.7 \%$ & 60 & $63.8 \%$ & \\
\hline & Divorced & 4 & $7.1 \%$ & 4 & $4.3 \%$ & \\
\hline & Not married & 5 & $8.9 \%$ & 4 & $4.3 \%$ & \\
\hline \multirow[t]{5}{*}{ Education } & Illeterate & 17 & $30.4 \%$ & 48 & $51.1 \%$ & \multirow[t]{5}{*}{0.012} \\
\hline & Can read and write & 12 & $21.4 \%$ & 19 & $20.2 \%$ & \\
\hline & Primary & 7 & $12.5 \%$ & 15 & $16.0 \%$ & \\
\hline & Secondry & 9 & $16.1 \%$ & 4 & $4.3 \%$ & \\
\hline & High level & 11 & $19.6 \%$ & 8 & $8.5 \%$ & \\
\hline \multirow[t]{9}{*}{ Comorbidities } & HTN only & 37 & $66.1 \%$ & 40 & $42.6 \%$ & \multirow[t]{2}{*}{0.005} \\
\hline & Other comorbidities with Htn & 19 & $33.9 \%$ & 54 & $57.4 \%$ & \\
\hline & $\mathrm{DM}$ & 7 & $12.5 \%$ & 30 & $31.9 \%$ & 0.008 \\
\hline & $\mathrm{HF}$ & 13 & $23.2 \%$ & 18 & $19.1 \%$ & 0.552 \\
\hline & Stroke & 3 & $5.4 \%$ & 10 & $10.6 \%$ & 0.266 \\
\hline & Ischemic HD & 2 & $3.6 \%$ & 14 & $14.9 \%$ & 0.030 \\
\hline & Malignancy & 2 & $3.6 \%$ & 12 & $12.8 \%$ & 0.061 \\
\hline & Renal failure & 4 & $7.1 \%$ & 16 & $17.0 \%$ & 0.085 \\
\hline & Liver cell failure & 6 & $10.7 \%$ & 12 & $12.8 \%$ & 0.708 \\
\hline \multirow{4}{*}{$\begin{array}{l}\text { Mini mental status } \\
\text { examination }\end{array}$} & MCI & 5 & $8.9 \%$ & 28 & $29.8 \%$ & \multirow{4}{*}{0.000} \\
\hline & Moderete dementia & 2 & $3.6 \%$ & 15 & $16.0 \%$ & \\
\hline & Severe dementia & 1 & $1.8 \%$ & 8 & $8.5 \%$ & \\
\hline & Not deminted & 48 & $85.7 \%$ & 43 & $45.7 \%$ & \\
\hline \multirow[t]{2}{*}{ GDs } & Depressed & 13 & $23.2 \%$ & 43 & $45.7 \%$ & \multirow[t]{2}{*}{0.006} \\
\hline & Not depressed & 43 & $76.8 \%$ & 51 & $54.3 \%$ & \\
\hline \multirow[t]{3}{*}{$\mathrm{ADL}$ and IADL } & Independent & 38 & $67.9 \%$ & 33 & $35.1 \%$ & \multirow[t]{3}{*}{0.000} \\
\hline & Assisted & 17 & $30.4 \%$ & 46 & $48.9 \%$ & \\
\hline & Dependent & 1 & $1.8 \%$ & 15 & $16.0 \%$ & \\
\hline
\end{tabular}

Table (4): Comparison between adherent and non-adherent cases regarding duration, occupation, income, living and smoking

\begin{tabular}{|c|c|c|c|c|c|c|}
\hline \multirow{4}{*}{$\begin{array}{l}\text { Duration of } \\
\text { hypertension }\end{array}$} & \multirow[b]{3}{*}{6 months - 1 year } & \multicolumn{2}{|c|}{ Adherent } & \multicolumn{2}{|c|}{ Non adherent } & \multirow{2}{*}{ P-value } \\
\hline & & No. & $\%$ & No. & $\%$ & \\
\hline & & 29 & $51.8 \%$ & 20 & $21.3 \%$ & \multirow[t]{3}{*}{0.000} \\
\hline & $1-10$ years & 22 & $39.3 \%$ & 36 & $38.3 \%$ & \\
\hline & $>10$ years & 5 & $8.9 \%$ & 38 & $40.4 \%$ & \\
\hline \multirow[t]{2}{*}{ Occupation } & Working & 24 & $42.9 \%$ & 15 & $16.0 \%$ & \multirow[t]{2}{*}{0.000} \\
\hline & Not working & 32 & $57.1 \%$ & 79 & $84.0 \%$ & \\
\hline \multirow[t]{3}{*}{ Income } & Enough and saving & 7 & $12.5 \%$ & 4 & $4.3 \%$ & \multirow[t]{3}{*}{0.000} \\
\hline & Enough & 20 & $35.7 \%$ & 11 & $11.7 \%$ & \\
\hline & Not enough & 29 & $51.8 \%$ & 79 & $84.0 \%$ & \\
\hline \multirow[t]{2}{*}{ Living } & Living alone & 14 & $25.0 \%$ & 16 & $17.0 \%$ & \multirow[t]{2}{*}{0.237} \\
\hline & Family size & 42 & $75.0 \%$ & 78 & $83.0 \%$ & \\
\hline \multirow[t]{2}{*}{ Smoking } & Smoking & 11 & $19.6 \%$ & 35 & $37.2 \%$ & \multirow[t]{2}{*}{0.024} \\
\hline & Not smoking & 45 & $80.4 \%$ & 59 & $62.8 \%$ & \\
\hline
\end{tabular}


Table (5): comparison between adherent and non-adherent case regarding polypharmacy, Antihypertensive drugs, other medication and how to buy them

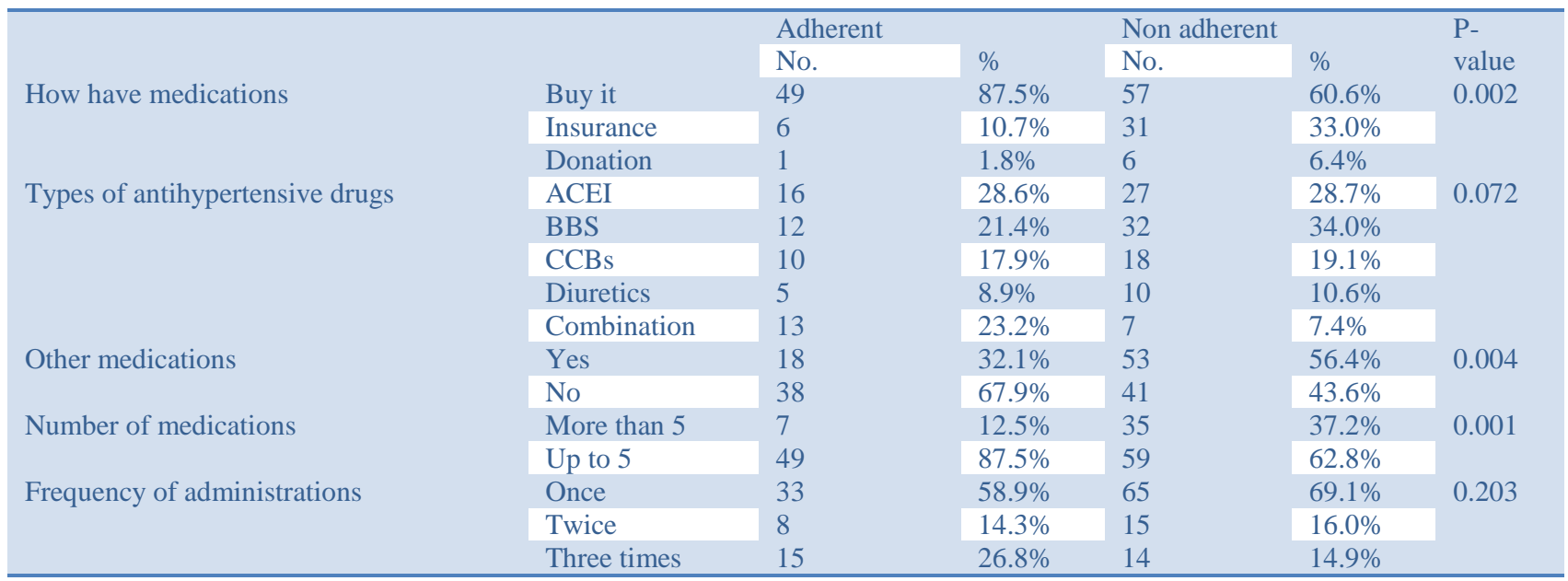

Table (6): comparison between adherent and non-adherent regarding controlling of hypertension, geriatric domains numerical, side effects of hypertensive drugs

\begin{tabular}{|c|c|c|c|c|c|c|}
\hline & & \multicolumn{2}{|c|}{ Adherent } & \multicolumn{2}{|c|}{ Non adherent } & \multirow[t]{2}{*}{$\mathrm{P}$-value } \\
\hline & & No. & $\%$ & No. & $\%$ & \\
\hline \multirow[t]{2}{*}{ HTN controlled } & Yes & 35 & $62.5 \%$ & 3 & $3.2 \%$ & \multirow[t]{2}{*}{0.000} \\
\hline & No & 21 & $37.5 \%$ & 91 & $96.8 \%$ & \\
\hline \multirow[t]{3}{*}{ MMSE } & $21-30$ & 51 & $91.1 \%$ & 63 & $67.0 \%$ & \multirow[t]{3}{*}{0.004} \\
\hline & $10-20$ & 4 & $7.1 \%$ & 23 & $24.5 \%$ & \\
\hline & $<10$ & 1 & $1.8 \%$ & 8 & $8.5 \%$ & \\
\hline \multirow[t]{7}{*}{ ADL } & Score 0 & 0 & $0.0 \%$ & 4 & $4.3 \%$ & \multirow[t]{7}{*}{0.000} \\
\hline & Score 1 & 1 & $1.8 \%$ & 12 & $12.8 \%$ & \\
\hline & Score 2 & 1 & $1.8 \%$ & 21 & $22.3 \%$ & \\
\hline & Score 3 & 5 & $8.9 \%$ & 20 & $21.3 \%$ & \\
\hline & Score 4 & 13 & $23.2 \%$ & 14 & $14.9 \%$ & \\
\hline & Score 5 & 19 & $33.9 \%$ & 13 & $13.8 \%$ & \\
\hline & Score 6 & 17 & $30.4 \%$ & 10 & $10.6 \%$ & \\
\hline \multirow{7}{*}{$\begin{array}{l}\text { Side effects of } \\
\text { antihypertensive }\end{array}$} & None & 32 & $57.1 \%$ & 45 & $47.9 \%$ & \multirow[t]{7}{*}{0.482} \\
\hline & $\begin{array}{l}\text { Dry Cough with ACEI or metallic } \\
\text { taste }\end{array}$ & 9 & $16.1 \%$ & 14 & $14.9 \%$ & \\
\hline & Dizziness with alpha blockers & 0 & $0.0 \%$ & 0 & $0.0 \%$ & \\
\hline & $\begin{array}{l}\text { Lower limb edema with calcium } \\
\text { channel blockers }\end{array}$ & 9 & $16.1 \%$ & 13 & $13.8 \%$ & \\
\hline & $\begin{array}{l}\text { Sexual impairment with beta } \\
\text { blockers }\end{array}$ & 1 & $1.8 \%$ & 4 & $4.3 \%$ & \\
\hline & Other side effects & 1 & $1.8 \%$ & 8 & $8.5 \%$ & \\
\hline & Poly urea with diuretics & 4 & $7.1 \%$ & 10 & $10.6 \%$ & \\
\hline
\end{tabular}

\section{Discussion}

In the study, it was found that the mean age among In this study, According to Hill Bone Scale for assessment of adherence to anti-hypertensive medications the prevalence was $62.7 \%$ of the studied cases were non adherent to medications, while $37.3 \%$ were adherent to their antihypertensive medications.

In the study by Khanam M A et (18) al12among people of rural Bangladesh the prevalence of non-adherence to treatment hypertension was $26.2 \%$ in the study population ( 25 years and above) which was low in comparison to this study. This wide difference in the prevalence of non-adherence compared to our study could be because the study participants were aged 25 years above and in our study the age of the participants was 60 years and above.

Studies from other parts of the globe have reported the prevalence of adherence to hypertensive medications to be ranging from $60 \%$ to $77 \%$. $19-20$

Age is highly significant predictor of non-adherence in this study as in older patients' percentage of nonadherence to anti-hypertensive medications increases .In other studies there was a specific focus on antihypertensive medication adherence in one age 
group, patients aged 65 years and above. In a cohort study of 2,180 hypertensive patients aged 65 years and older who were randomly selected from the roster of a large managed care organisation in South-eastern Louisiana (Krousel-Wood et al., 2010)(21), and another cross-sectional study that used data from the Chronic Condition Data Warehouse of the Centers for Medicare and Medicaid Services in America of 9,827 older adults diagnosed with hypertension, chronic heart failure and age-related problems (e.g. Dementia)(22) (Rattinger et al., 2012), Age was found to be a significant predictor of the level of adherence. Their findings suggested that older adult hypertensive patients are less adherent to their medications (Krousel-Wood, et al., 2010; Murray \& Callahan, 2003; Rattinger, et al., 2012). (22-25) Such poor adherence among patients older than 65 years could be explained as related to some aging-related health conditions such as loss of cognition and vision problems which make it difficult for them to adhere to their treatments(26) (Rattinger et al., 2012).

The present study showed that marrital status is a significant factor for antihypertensive medication adherence, as married patients have adherence levels more than widow, divorced or not married hypertensive patients. Some studies suggest that adherence to medication for patients with hypertension is higher among those who are married, and appear to have better control of their hypertension (DiMatteo, 2004;Ayotte etal., 2008). The present study showed that income is a highy significant factor for adherence to antihypertensive medications in hypertensive elderly patients. Patients' income was a significant predictor of antihypertensive

medications in this study if it was enough and saving, enough, or not enough some studies found that patients' financial situation was a significant predictor for medication adherence (Khanam et al., 2014; Gemilyan et al., 2008), because hypertensive patients with low incomes struggled to adhere to antihypertensive medications due to their cost (Herttua et al., 2013) Antihypertensive medications are long term medications that need continual replenishing. One of the barriers in adherence to medications is the cost which hinders the continuity of treatment for patients with low incomes (Herttua et al., 2013).

Patient's level of education is a significant predictor of antihypertensive medication adherence in the current study

therefore educated patients were expected to report better adherence to medications compared to patients with less or no educational backgrounds (Bader et al., 2015)

However, the fact that poor health literacy is an issue that can be found in educated and uneducated patient groups alike indicates that medication adherence can be identified as an issue for both patients groups. (Baker et al.,2003). Health literacy levels can be improved by providing information about the illness and its treatment (van der Heide et al., 2013).
Medication adherence for patients with hypertension that have been recently diagnosed often shows lower levels when compared to patients diagnosed with hypertension over a longer term (Mazzaglia et al., 2009; Ramli, et al , 2012).

Previous studies show that consistent adherence to medication is often poor during the first six months after initial diagnosis, but this inconsistent adherence behavior can continue for up to four years (Mazzaglia et al., 2009)

In this study, we found that patients who are newly diagnosed as hypertensive patients are more adherent to treatment more than who have long standing hypertension and on long term treatment and showed a highly significant predictor for adherence or nonadherence

The presence of comorbidities was a highly significant predictor of antihypertensive medications adherence in the current study, as patients with hypertension only are more adherent to antihypertensive Medications more than hypertension with other comorbidities

This is in line with a study conducted in the United Arab Emirates with 250 hypertensive patients (Bader et al., 2015). In contrast, a previous study in the USA found patients with diabetes and hypertension were more likely than those with only hypertension to adhere to prescribed medications, as they had multiple health issues that required multiple medications (Loeppke et al., 2011). The authors argued that patients with multiple symptoms from comorbidities and hypertension need to adhere to prescribed medications in order to control their symptoms effectively. Another explanation proposed by (Hashmi et al. 2007) is that patients taking multiple medications are more cautious with their treatments compared with those who receive a single therapy (Hashmi et al., 2007).

Possible reasons for patients with comorbidities to adhere better to their medications is because they perceive more strongly the seriousness of their health condition and want to prevent further complications, in addition to experiencing more frequent or more severe symptoms of their other conditions which encourage them to adhere to their medications.

Patients with psychological conditions such as depression are at increased risk for medication nonadherence (Bautista et al., 2012; Maguire et al., 2008) Studies have found that patients who experience some psychological symptoms encounter difficulties with managing their health illness (Bautista et al., 2012; Maguire et al., 2008). The effect of these symptoms is mainly on patients' perceptions of their capacity to care for themselves in their illness (Maguire et al., 2008) 
In this study, we found that GDS was highly significant predictor for adherence. Mini mental status of examination is an important tool for adherence, In this study we found that non demented patient are the commonest group adherent to anti-hypertensive medications, and severe dementia are least group adhere to medications. ADL, IADL were important tools for adherence, In the study we found that ADL and IADL were highly significant predictor for adherence

\section{Conclusion:}

The problem of non-adherence is universal and not just limited to developed or developing countries. But its impact may be more on those countries with limited resources since poor adherence poses a huge challenge for improving health in poor populations, and also results in underutilization of already limited treatment resources.

\section{Conflict of Interests}

The author has no conflict of interests to declare regarding the publication of this paper.

\section{References}

1- Tadesse M, Eyob A, Akshay S, Asim A. Nonadherence to antihypertensive drugs. A systematic review and meta-analysis. Medicine. 2017;96:e5647. doi: 10.1097/MD.0000000000005647

2- Hussanin SM, Boonshuyar C, Ekram A. Non-adherence to antihypertensive treatment in essential hypertensive patients in Rajshahi, Bangladesh. Anwer Khan Modern Med Coll J. 2011;2:9-14. doi: 10.3329/akmmcj.v2i1.7465.

3- Nguyen T-P-L, Schuiling-Veninga CCM, Nguyen TBY, Vu T-H, Wright EP, Postma MJ. Adherence to hypertension medication: quantitative and qualitative investigations in a rural northern Vietnamese community. PLoS One. 2017;12:e0171203. doi: 10.1371/journal.pone.0171203

4- Boima V, Ademola AD, Odusola AO, Agyekum F, Nwafor CE, Cole $\mathrm{H}$, et al. Factors Associated with Medication Nonadherence among Hypertensives in Ghana and Nigeria. Int J Hypertens [Internet]. 2015; Availablefrom: https://www.hindawi.com/journals/ijhy/20 15/205716/. [cited 29 May 2018] [PMC free article] [PubMed]

5- $\quad$ Busari O, Olanrewaju T, Desalu O, Opadijo O, Kayode $\mathrm{J}$, Agboola S, et al. Impact of PatientsAND\#8217; Knowledge, Attitude and Practices on Hypertension on Compliance with Antihypertensive Drugs in a Resourcepoor Setting. 2010.

6- DE, Muntner P. New Medication Adherence Scale Versus Pharmacy Fill Rates in Seniors With Hypertension. Am J Manag Care 2009;15(1):59-66.

7- Morisky DE, DiMatteo MR. Improving the measurement of self-reported medication poor adherence: Final response. J ClinEpidemio 2011; 64:258-263. PMID:21144706

8- Sheilini $M$ et al. Antihypertensive Treatment, Medication- Non-Adherence and Factors Leading toNon-Adherence Among Elderly Manipaluniversity,manipal
9- Kumar $\mathrm{N}$ et. al. Factors associated with adherence to antihypertensive treatment among patients attending a tertiary care hospital in Mangalore, South india

10- Khanam M A, Lindeboom W, Koehlmoos T L P, Alam D $S$, Niessen $L$ and Milton $A H$ Hypertension: adherence to treatment in rural Bangladesh findings from a population based study in Bangladesh.

11- Hsu YH, Mao CL, Wey M. Antihypertensive Medication Adherence among Elderly Chinese Americans. J Transcult- Nurs 2010; 21(4):297- 305.

12- Ramli A, Ahmad NS, Paraidathathu T. Medication adherence among hypertensive patients of primary health clinics in Malaysia. Patient Prefer Adherence $2012 ; 6: 613-22$

13- Dessie A, Asres G, Meseret S, Birhanu Z Adherence to antihypertensive treatment and associated factors among patients on follow up at University of Gondar Hospital, Northwest Ethiopia. BMC Public Health 2012; 12:282.

14- Lowry KP, Dudley TK, Oddone EZ, Bosworth HB. Intentional and unintentional nonadherence to antihypertensive medication. Ann Pharmacother. 2005; 39(7-8):1198-203

15- Lee GK, Wang HH, Liu KQ, Cheung Y, Morisky DE, Wong MC. Determinants of medication adherence to antihypertensive medications among a Chinese population using Morisky Medication Adherence Scale. PLoS One 2013; 8 (4): e62775 doi:10.1371/journal.pone.0062775

16- . Patel RP, Taylor SD. Factors affecting medication adherence in hypertensive patients.AnnPharmacother 2002; 36 (1):40-5.

17- Atulomah NO, Florence MO, Oluwatosin A. Treatment adherence and risk of non-compliance among hypertensives at a Teaching Hospital in Ogun state, southwest Nigeria.acta SATECH 2010; 3(2):143- 149.

18- Chelkeba L, Dessie S. Antihypertension medication adherence and associated factors at Dessie Hospital, North East Ethiopia, Ethiopia. Int J Res Med Sci 2013;1(3):191-197.

19- Hashmi SK, Afridi MB, Abbas K, Sajwani RA, Saleheen $D$, Frossard PM et al.Factors associated with adherence to antihypertensive treatment in Pakistan. PLoS One. 2007 Mar 14;2 (3):e280

20- Susan R, Anu K, Achu T, Soumya G, Vijayakumar K, Anish TS.Antihypertensive Drug Compliance across Clinic and Community Settings, in Thiruvananthapuram, South India.

21- Caro JJ, Salas M, Speckman JL, Raggio G, Jackson JD. Persistence with treatment for hypertension in actual practice.CMAJ. 1999;160(1): 31-37 